\title{
Antimutagenic, antiproliferative, and antioxidant effect of extracts obtained from octopus (Paraoctopus limaculatus)
}

\author{
Susana-Gabriela CRUZ-RAMÍREZ11, Carmen-María LÓPEZ-SAIZ², Ema-Carina ROSAS-BURGOS ${ }^{1}$, \\ Francisco-Javier CINCO-MOROYOQUI ${ }^{1}$, Carlos VELÁZQUEZ ${ }^{3}$, Javier HERNÁNDEZ ${ }^{4}$, \\ Armando BURGOS-HERNÁNDEZ ${ }^{1 *}$
}

\begin{abstract}
The search for chemopreventive/chemoprotective compounds in marine organism has been extensively reported; however, the presence of these compounds in octopus has been incipiently explored. In this research, the antimutagenic, antiproliferative, and antioxidant potential of three crude extracts (methanolic, acetonic, and hexanic) from Paroctopus limaculatus was investigated. Antimutagenic activity against aflatoxin $\mathrm{B}_{1}\left(\mathrm{AFB}_{1}\right)$ was evaluated through the Ames test using Salmonella typhimurium tester strains TA98 and 100. Antiproliferative activity was assessed using the standard MTT (3-(4,5-dimethyl-2-thiazolyl)-2,5diphenyl-2-H-tetrazolium bromide) assay on M12.C3.F6 murine cell line. Antioxidant activity was assessed using the DPPH (2,2-diphenyl-1-picrylhydrazyl) and ABTS (2,2'-Azino-bis(3-ethylbenzothiazoline-6-sulfonic acid) methods. Hexanic extract showed the highest antimutagenic and antiproliverative activities inhibiting 80 and $43 \%$ of mutagenicity induced by $\mathrm{AFB}_{1}$ for TA98 and TA100, respectively, and showing a high antiproliferative activity at 200 and $100 \mu \mathrm{g} / \mathrm{mL}$. However, when the antioxidant activity was evaluated at a concentration of $50 \mathrm{mg} / \mathrm{mL}$, the methanolic fraction exerted inhibition of 98 and $96 \%$ ABTS and DPPH radicals, respectively. RP-HPLC and ${ }^{1} \mathrm{H}-\mathrm{RMN}$ analyses suggested the presence of double bonds with extended conjugation and oxygenated compounds such as alcohols, esters, ethers or ketones. These results suggested that hexanic and methanolic extract form octopus contained compounds with chemoprotective and antioxidant properties.
\end{abstract}

Keywords: octopus; biological activity; chemopreventive.

Practical Application: Octopus fractions can be used as potential chemopreventive and antioxidant compounds.

\section{Introduction}

Cancer is the leading cause of mortality worldwide and the number of cases is increasing every year (World Health Organization, 2010). Chemoprevention is a long-term strategy with the best cost-effectiveness ratio for cancer control, which consists in the use of certain chemicals, natural or synthetic, with the aim of preventing carcinogenesis or reversing the development of invasive malignancy (Martínez, 2006). In recent years, the marine environment has been recognized as a resource with high biodiversity but still unexplored. Nowadays is considered a potential source of novel bioactive compounds as new anticancer agents (Pramanik \& Pandey, 2013).

A marine source of bioactive compounds are cephalopods which include nautilus, cuttlefishes, squids, and octopus that constitute an important source of many biological substances with antioxidant, antitumor, antileukemic, antibacterial, and antiviral activities (Rajaganapathi et al., 2000, Jayaraj et al., 2008, Jesy et al., 2014, Sudhakar \& Nazeer, 2015). These researches suggest that these marine invertebrate may become an important source of new compounds with potential application in biomedicine.
Octopus is one of the species that has been reported as source of bioactive compounds with accentuated antiproliferative and antimutagenic activities, which are able to reverse the mutation of aflatoxin $\mathrm{B}_{1}\left(\mathrm{AFB}_{1}\right)$ and also selectively act against the proliferation of tumor cells (Moreno-Félix et al., 2013). These antimutagenic compounds extracted with chloroform from octopus, were identified as butyl isobutyl phthalate derivatives (Cruz-Ramírez et al., 2015). Based on the above, the aim of this study was to assess the antimutagenic, antiproliferative, and antioxidant activities exerted by compounds in fractions from octopus.

\section{Materials and methods}

\subsection{Bacterial cultures and cell lines}

Salmonella typhimurium TA98 and TA100 (Molecular Toxicology Inc.) were routinely checked to confirm genetic features using the procedure described by Maron \& Ames (1983). 
Cell line M12.C3.F6 (murine B-cell lymphoma) was kindly provided by Dr. Emil R. Unanue (Department of Pathology and Immunology, Washington University at St. Louis, MO, USA). M12.C3.F6 was cultured in Dulbecco's modified Eagle's medium (DMEM) (Gibco, Grand Island, NY, USA), supplemented with $5 \%$ fetal calf serum and grown at $37^{\circ} \mathrm{C}$ at $5 \% \mathrm{CO}_{2}$.

\subsection{Testing species}

Octopus (Paraoctopus limaculatus) was obtained from Bahía de Kino, Sonora, México (29 22’ 27” N, $112^{\circ} 34^{\prime} 08^{\prime \prime}$ O) and transported in ice to the University of Sonora, Seafood Laboratory. Organism were fresh packed and stored at $-25{ }^{\circ} \mathrm{C}$ until further analysis. Tentacles were minced, separated in homogeneous portions and freeze-dried at $-30{ }^{\circ} \mathrm{C}$ under vacuum (Unitop 600L, USA).

\subsection{Extraction of bioactive compounds}

A $40 \mathrm{~g}$ portion of lyophilized octopus tentacles was homogenized with $500 \mathrm{~mL}$ hexane and the mixture agitated for $60 \mathrm{~min}$ using a Burrell Wrist Action Shaker (Burrell Corporation Pittsburgh, PA). Then, the mixture was filtered through Whatman No. 42 filter paper under vacuum and the solvent was evaporated using a rotary evaporator (Yamato RE300 Scientific Co., Ltd, Japan) to dryness under a nitrogen stream and darkness (LópezSaiz et al., 2014) in order to obtain the hexane soluble fraction (HSF). The residue obtained after filtration was subjected to the same procedure described above using acetone and later with methanol, in order to obtain the acetone- (ASF) and methanolsoluble fractions (MSF), respectively. Yields (dry basis) of the three fractions were quantified. Octopus fractions were used to assess biological activities.

\subsection{Antimutagenicity Assay}

The antimutagenic potential of the three extracts was evaluated using the mutagenicity assay described by Maron \& Ames (1983) with Salmonella typhimurium TA98 and TA100 as tester strains in the presence of metabolic activation ( $\mathrm{S} 9 \mathrm{mix}$ ). Fractions were reconstituted and serially diluted with dimethyl sulfoxide (DMSO) and then spiked with enough pure $\mathrm{AFB}_{1}$ to achieve a common final concentration of $500 \mathrm{ng}$ of $\mathrm{AFB}_{1} / 100 \mu \mathrm{L}$. Different $\mathrm{AFB}_{1}$ concentrations were used as positive controls for both strains. All assays were performed in triplicate.

\subsection{Antiproliferation assay}

The antiproliferative effect of octopus fractions was determined using the standard MTT (3-(4,5-dimethylthiazol-2-yl)-2,5diphenyltetrazolium bromide) assay (Mosmann, 1983) using M12.C3.F6 (murine B-cell lymphoma) cell line. Fifty- $\mu$ L aliquots of murine B-cell lymphoma culture were placed in wells of a flat 96-well plate (10,000 cells/ well) and then incubated for $12 \mathrm{~h}$ at $37^{\circ} \mathrm{C}$ in an atmosphere of $5 \% \mathrm{CO}_{2}$ to allow cell attachment. Cell cultures were incubated with $50 \mu \mathrm{L}$ of medium containing various concentrations of extract $(200,100$, and $50 \mu \mathrm{g} / \mathrm{mL})$ and incubated for $48 \mathrm{~h}$. Extracts were first re-suspended in DMSO and diluted in supplemented Dulbecco's Modified Eagle's Medium
(DMEM) media. Control cell cultures were incubated with DMSO (final DMSO concentration $0.2 \% \mathrm{v} / \mathrm{v}$ ). Prior to the last $4 \mathrm{~h}$ of the cell culture, $10 \mu \mathrm{L}$ of a MTT stock solution $(5 \mathrm{mg} / \mathrm{mL})$ were added to each well and after this time, the formazan crystals formed were dissolved with acidic isopropanol ( $100 \mu \mathrm{l}$ of $0.04 \mathrm{~N}$ $\mathrm{HCI}$ in isopropanol). Plates were read in an ELISA plate reader (Benchmark Microplate Reader; Bio-Rad, Hercules, CA, USA) using a test wavelength of $570 \mathrm{~nm}$ and a reference wavelength of $630 \mathrm{~nm}$. Plates were read within $15 \mathrm{~min}$ after adding isopropanol. Results were expressed as percentages of cell proliferation.

\subsection{Antioxidant assay}

Scavenging activity on 2,2-diphenyl-l-picrylhydrazyl (DPPH) radical assay

DPPH radical scavenging activity was determined according to the method described by Jie Li et al. (2012) with slight modifications. In this method, $50 \mu \mathrm{L}$-aliquots of octopus fractions at different concentrations $(50,25,10,5$, and $2.5 \mathrm{mg} / \mathrm{mL})$ were placed into wells of 96-well plates and then combined with $200 \mu \mathrm{L}$ of a DPPH hexane-ethanol (1:1) solution ( $4 \mathrm{mg} / 100 \mathrm{~mL}$ of solution). Each well was mixed and incubated in the dark for $30 \mathrm{~min}$ at room temperature. The absorbance was measured at $540 \mathrm{~nm}$ in microplate reader (BIO-RAD xMark ${ }^{\mathrm{m}}$, México). Antioxidant capacity was calculated using the following Equation 1:

DDPH scavenging activity $(\%)=\frac{(1-\lambda 540-\mathrm{s})}{\lambda 540-c} \times 100$

Where $\lambda 540{ }_{\mathrm{s}}$ is the absorbance of the remaining DPPH in the presence of the scavenger and $\lambda 540{ }_{\mathrm{C}}$ is the absorbance of the control with no radical scavenger.

Scavenging activity on 2,2'-Azino-bis(3-ethylbenzothiazoline6-sulfonic acid (ABTS) radical assay

The ABTS radical assay was determined according to Jie Li et al. (2012), modified as described below. The ABTS radical solution was prepared by dissolving $8 \mathrm{mg}$ of the radical in $1 \mathrm{~mL}$ of $\mathrm{H}_{2} \mathrm{O}$, reacted with an equal volume (1:1) of a potassium persulfate $\left(\mathrm{K}_{2} \mathrm{~S}_{2} \mathrm{O}_{8}\right)(1.3 \mathrm{mg} / \mathrm{mL})$ solution, and then stored for $16 \mathrm{~h}$ in the dark at room temperature. Fifty- $\mu \mathrm{L}$-aliquots of octopus fractions at different concentrations $(50,25,10,5$, and $2.5 \mathrm{mg} / \mathrm{mL})$, were placed into wells of 96 -well plates and then combined with $200 \mu \mathrm{L}$ of a previously activated ABTS radical solution. Each well was mixed and incubated in the dark for $30 \mathrm{~min}$ at room temperature. The absorbance was measure at $713 \mathrm{~nm}$ in microplate reader (BIO-RAD xMark ${ }^{\mathrm{TM}}$, México). The antioxidant capacity was calculated using the following Equation 2:

ABTS scavenging activity $(\%)=\frac{(1-\lambda 713-\mathrm{s})}{\lambda 713-c} \times 100$

Where $\lambda 71{ }_{-}{ }_{s}$ is the absorbance of the remaining ABTS in the presence of scavenger and $\lambda 713{ }_{-}{ }_{C}$ is the absorbance of the control with no radical scavenger. 


\subsection{Qualitative analysis by RP-HPLC}

The objective of this analysis was to determine the compositional complexity octopus fractions and the retention times of the main compounds in them. The experiment was carried out in an Agilent Technologies 1260 Infinity High Performance Liquid Chromatoph equipped with a photodiode detector, a Zorbax Eclipse XDB-C18 semipreparative column ( $5 \mu \mathrm{m}$ particle size, $250 \times 9.4 \mathrm{~mm}$ i.d.), and a $20 \mu \mathrm{L}$-injection loop. Column temperature was set at $20^{\circ} \mathrm{C}$. Elution of components was carried out at a flow rate of $2 \mathrm{ml} / \mathrm{min}$ using a linear gradient from 50:50 to 0:100 during the first 9 min mobile phase consisting of a water/methanol mixture followed by acetone/hexane (100:0) during $20 \mathrm{~min}$ and concluding with 100\% hexane over $35 \mathrm{~min}$. All of the three octopus fractions were monitored at $350 \mathrm{~nm}$ and scanned (190 to $600 \mathrm{~nm}$ ) to detect maximum absorption values.

\section{$2.8{ }^{1} \mathrm{H}-\mathrm{NMR}$ Analysis}

Hexanic and menthanolic octopus fractions were dissolved in deuterated chloroform $\left(\mathrm{CDCl}_{3}\right)$ and analyzed by ${ }^{1} \mathrm{H}-\mathrm{NMR}$. Measurements were carried out in a Bruker Avance $400 \mathrm{MHz}$ equipment using tetramethylsilane (TMS) as reference.

\subsection{Statistical analysis}

The statistical analysis was performed using the software JMP (Visual statistical discovery software, 5.01). Data were analyzed by ANOVA followed by a Tukey-Kramer test $(\mathrm{P}<0.05)$.

\section{Results and discussion}

\subsection{Extraction yield}

The extraction of octopus compounds was carried out using three different solvents: methanol, acetone, and hexane, obtaining the highest yield ( $16.91 \%$ dry basis) with methanol. Athukorala et al. (2003) obtained similar results reporting that methanol was one of the most effective organic solvents for compounds extraction from a marine alga achieving an $18.4 \%$ yield. Recently, Umayaparvathi et al. (2013), evaluated one methanolic extract from octopus and they obtained a $0.85 \%$ yield in wet basis. These last results showed a lower extraction yield compared to those obtained in our experiment, the differences may be related to the extraction process. On the other hand, the HSF and ASF showed the lowest yield with 1.45 and $0.45 \%$, respectively. These results suggest that methanol is an effective solvent to extract a wide range of compounds from octopus.

\subsection{Antimutagenic activity}

The antimutagenic potential of the three fractions obtained from octopus is shown in Table 1, which corresponds to both Salmonella typhimurium tester strains. The antimutagenic activities of MSF and ASF were not statistically ( $<<0.05$ ) different achieving 50 and $45 \%$ inhibition of $500 \mathrm{ng}$ of pure $\mathrm{AFB}_{1}$, respectively, when exposing tester strain TA98 to the highest octopus fraction concentration tested. Similar results were observed for TA100 tester strain, but in this case the octopus fraction used decreased the reversion rate achieved by $A F B_{1}$ by 13 and $2 \%$ for MSF and ASF.
However, the inhibition of the mutagenicity of $500 \mathrm{ng}$ AFB exerted by the HSF at $5 \mathrm{mg} / \mathrm{mL}$, was significantly $(\mathrm{p}<0.05)$ higher than that observed for the MSF or ASF. These results were also observed in both Salmonella tester strains, suggesting the presence of compounds that might protect the genetic material from suffering both types of mutation, base pair or frame-shift.

Stankevicins et al. (2008), evaluated the antimutagenic activity from two extract: acetone- and ethanol-soluble fractions, from the sponge Arenosclera brasiliensis, finding the acetone-soluble fraction was the most antimutagenic using Salmonella TA100 tester strain. More recently, extracts from the marine organism Sphyrna lewini were evaluated for antimutagenic potential by Samadi et al. (2011), revealing that methanolic extracts from cartilage exerted the highest antimutagenic effect against sodium azide (as a control mutagen).

Nevertheless, the antimutagenic activity of hexane-soluble fractions has been evaluated in medical plants such as Astragalus species (Gulluce et al., 2010). They found five hexane-soluble fractions with antimutagenic activity in Salmonella typhimurium TA1537 strain that may be due to their inhibition capabilities by blocking 9-AA binding to DNA in vitro. In this context, the results obtained in the present study are promising in finding biologically active compounds that might be candidates as possible cancer preventive agents.

\subsection{Antiproliferative activity}

The cell-growth inhibitory effect of octopus fractions on murine B-cell lymphoma cell line (M12.C3.F6) is shown in Figure 1. The HSF exhibited an antiproliferative activity significantly $(\mathrm{p}<0.05)$ higher than either MSF or ASF, tested at concentrations of 200 and $100 \mu \mathrm{g} / \mathrm{mL}$. On the other hand, whereas the ASF only inhibited approximately $20 \%$ cell proliferation, the MSF did not show inhibition of cellular proliferation compared to the control. Althunibat et al. (2009) evaluated the antiproliferative effects of aqueous and organic extracts from three species of sea cucumbers; the organic extract from the species Holothuria scraba inhibited the growth of both cancer cell lines, C33A (human cervix) and $\mathrm{A} 549$ (human lung), at cytotoxic concentrations $\left(\mathrm{IC}_{50}\right)$ of

Table 1. Revertants ${ }^{\dagger}$ induced by $\mathrm{AFB}_{1}{ }^{\S}$ spiked obtained of extracts from Paraoctopus limaculatus evaluated on Salmonella typhimurium TA98 and TA100 tester strain with S9.

\begin{tabular}{|c|c|c|c|}
\hline Octopus fraction & $5 \mathrm{mg} / \mathrm{mL}$ & $0.5 \mathrm{mg} / \mathrm{mL}$ & $0.05 \mathrm{mg} / \mathrm{mL}$ \\
\hline \multicolumn{4}{|l|}{ TA98 } \\
\hline Hexane-soluble & $133 \pm 4.1^{\mathrm{b}}$ & $373 \pm 11.3^{\mathrm{a}}$ & $523 \pm 10^{\mathrm{ab}}$ \\
\hline Acetone-soluble & $340 \pm 3.2^{\mathrm{a}}$ & $429 \pm 7.7^{a}$ & $476 \pm 5.8^{\mathrm{a}}$ \\
\hline Methanol-soluble & $312 \pm 1.4^{\mathrm{a}}$ & $385 \pm 7.4^{\mathrm{a}}$ & $358 \pm 5.1^{\mathrm{a}}$ \\
\hline \multicolumn{4}{|l|}{ TA100 } \\
\hline Hexane-soluble & $602 \pm 18.2^{b}$ & $694 \pm 6.3^{b}$ & $919 \pm 13.7^{\mathrm{a}}$ \\
\hline Acetone-soluble & $921 \pm 8.4^{a}$ & $1012 \pm 8.3^{\mathrm{a}}$ & $1048 \pm 5.6^{\mathrm{a}}$ \\
\hline Methanol-soluble & $1030 \pm 2.9^{\mathrm{a}}$ & $1052 \pm 1.5^{\mathrm{a}}$ & $1063 \pm 4.4^{\mathrm{a}}$ \\
\hline \multicolumn{4}{|c|}{$\begin{array}{l}\text { "Positive control } \mathrm{AFB}_{1}(500 \mathrm{ng} / \mathrm{plate}) \text { induced } 602 \pm 62 \text { and } 1051 \pm 69 \text { revertants/plate } \\
\text { for TA98 and TA100 tester strains, respectively. Spontaneous revertants were } 22 \pm 4 \\
\text { and } 96 \pm 6 \text { for TA98 and TA100 tester strains, respectively. }{ }^{\top} \text { Values are means of three } \\
\text { replicates } \pm \text { standard error mean. Different letters in a column represent significant } \\
\text { differences }(\mathrm{p}<0.05) \text {. }\end{array}$} \\
\hline
\end{tabular}


15.5 and $3.5 \mathrm{mg} / \mathrm{mL}$. Furthermore, recent research evaluated the antiproliferative effect of lipids fractions from octopus by-products on human breast cancer cell lines MCF-7 and MDA-MB-231. Two lipidic sub-fractions exhibited significant anti-proliferative effect on MC-7; authors found that compounds like sterols or terpenes present in octopus by-products may be responsible for these biological activity (Fitahia et al., 2015).

\subsection{Antioxidant activity}

Figure $2 \mathrm{a}$ and $2 \mathrm{~b}$ show the inhibition percentage for both radicals exerted by the three octopus fractions. MSF showed the highest percentage of radical inhibition at concentration of $50 \mathrm{mg} / \mathrm{mL}$ evaluated on ABTS radical-scavenging capacity.

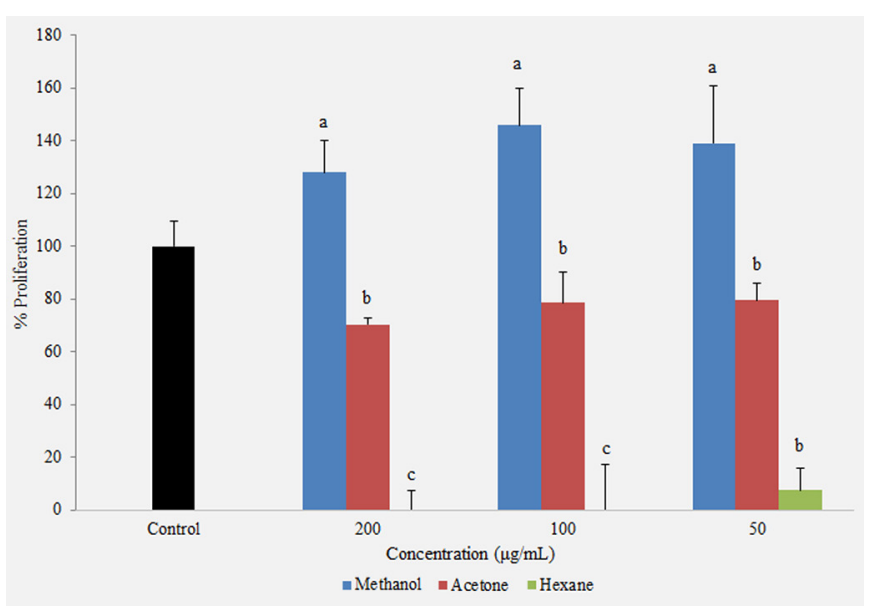

Figure 1. Antiproliferative effect of fractions obtained from octopus on transformed cell line M12.C3.F6 (murine B-cell lymphoma). All values are mean from three determinations. Values with the same letters are not significantly $(\mathrm{p}>0.05)$ different.

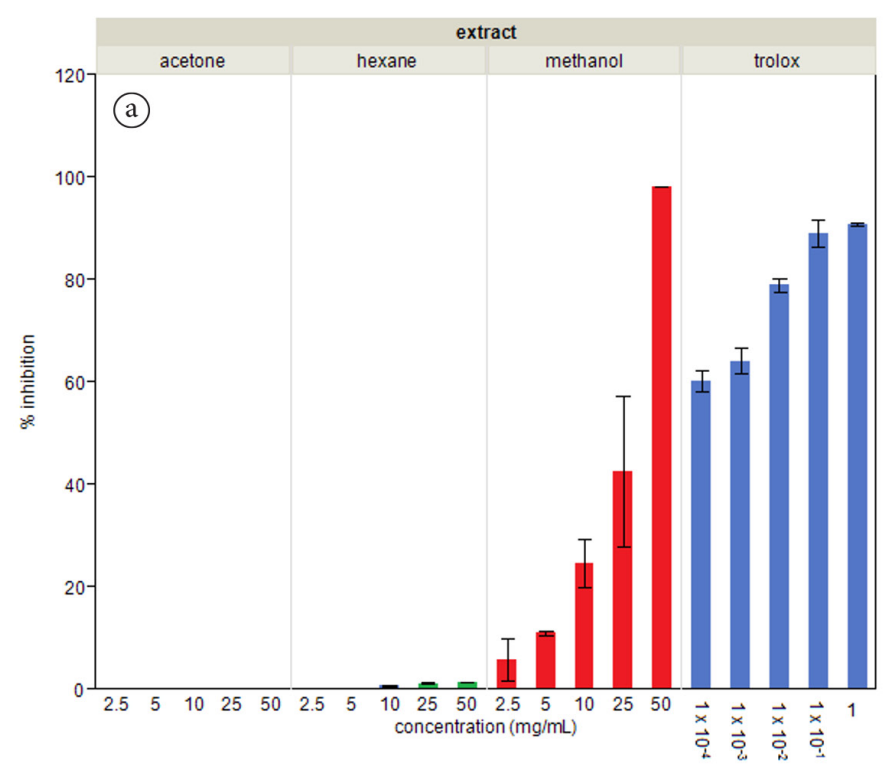

These results are consistent with the DPPH radical-scavenging capacity; bacause MSF exhibited values of $96.84,83.28,80.5,77.45$, and $75.98 \%$ at concentrations of $50,25,10,5$, and $2.5 \mathrm{mg} / \mathrm{mL}$, respectively. These results are supported by Senthilkumar \& Sudha (2012); they found a methanolic extract from seaweed Chaetomorpha linum that contains compounds with high scavenging activity attributed to phenolic $\mathrm{OH}$ groups, which are major contributors to antioxidant activity and anticancer effects. Moreover, peptide-like compounds have been isolated from marine organisms, which act as ROS radical scavengers, preventing DNA damage, and inhibiting lipidic peroxidation (Sudhakar \& Nazeer et al., 2015).

Many studies correlate the antimutagenic effect with antioxidant activity because antioxidant compounds may act in the early stages of carcinogenesis, either interacting with mutagens or by stabilizing free radicals that cause damage to genetic material (Aqil et al., 2008; Zahin et al., 2010a, b, 2013; Bhattacharya, 2011; Sultana et al., 2014). However, antimutagens present in the HSF were not able to act as antioxidant. The differences in scavenging antioxidant and antimutagenic activity may be due to polarity characteristic of compounds extracted with different solvents and to the mechanism of action by which they act.

\subsection{Qualitative analysis by RP-HPLC}

Chromatographical analysis and the spectrophotometric scanning of three fractions obtained from octopus are shown in Figure 3. Results of MSF analysis suggest the presence of polar compounds evidenced by the presence of signals at times $<10 \mathrm{~min}$. The highest absorption signals were observed at $350 \mathrm{~nm}$ but most were absorbed in the near UV spectrum.

The ASF emitted signals at retention times similar to those observed (10 $\mathrm{min}$ ) for the MSF, but also this fraction emitted signals at retention times $>10 \mathrm{~min}$, suggesting the presence of



Figure 2. Antioxidant activity of acetone-, hexane-, and methanol-soluble fractions obtained from octopus (Paraoctopus limaculatus) against ABTS (a) and DPPH (b) radicals. Values are means \pm SD of triplicate experiments. 


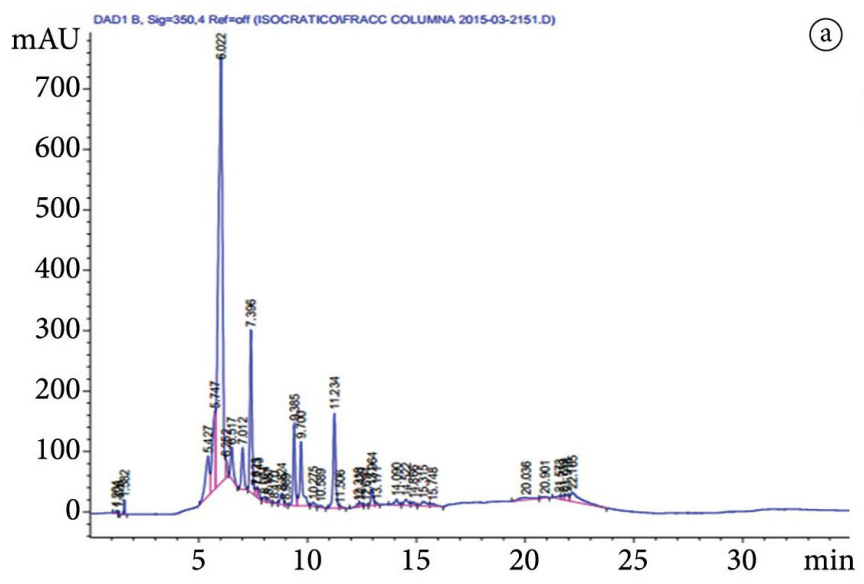

(a)
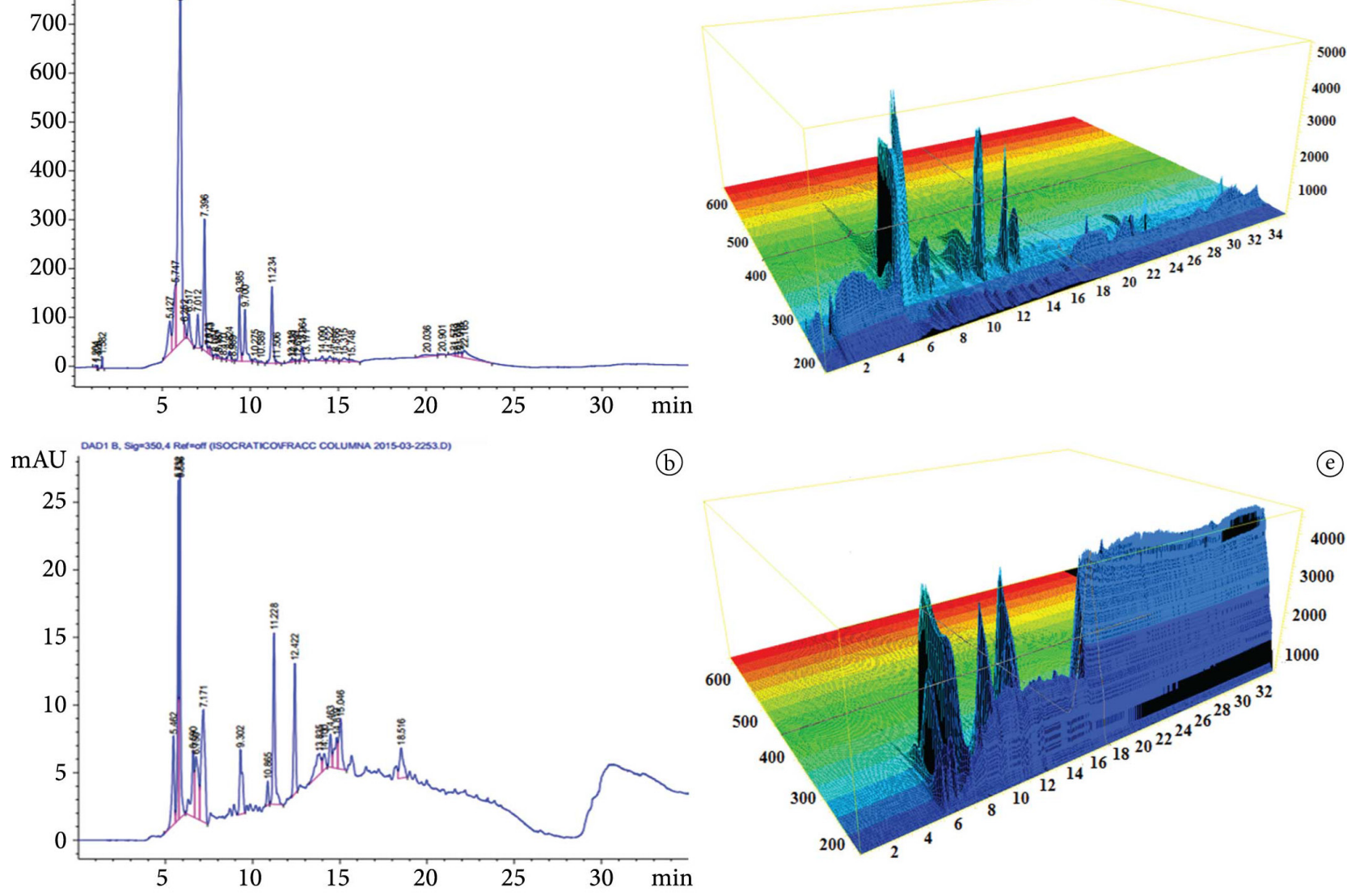

(b)
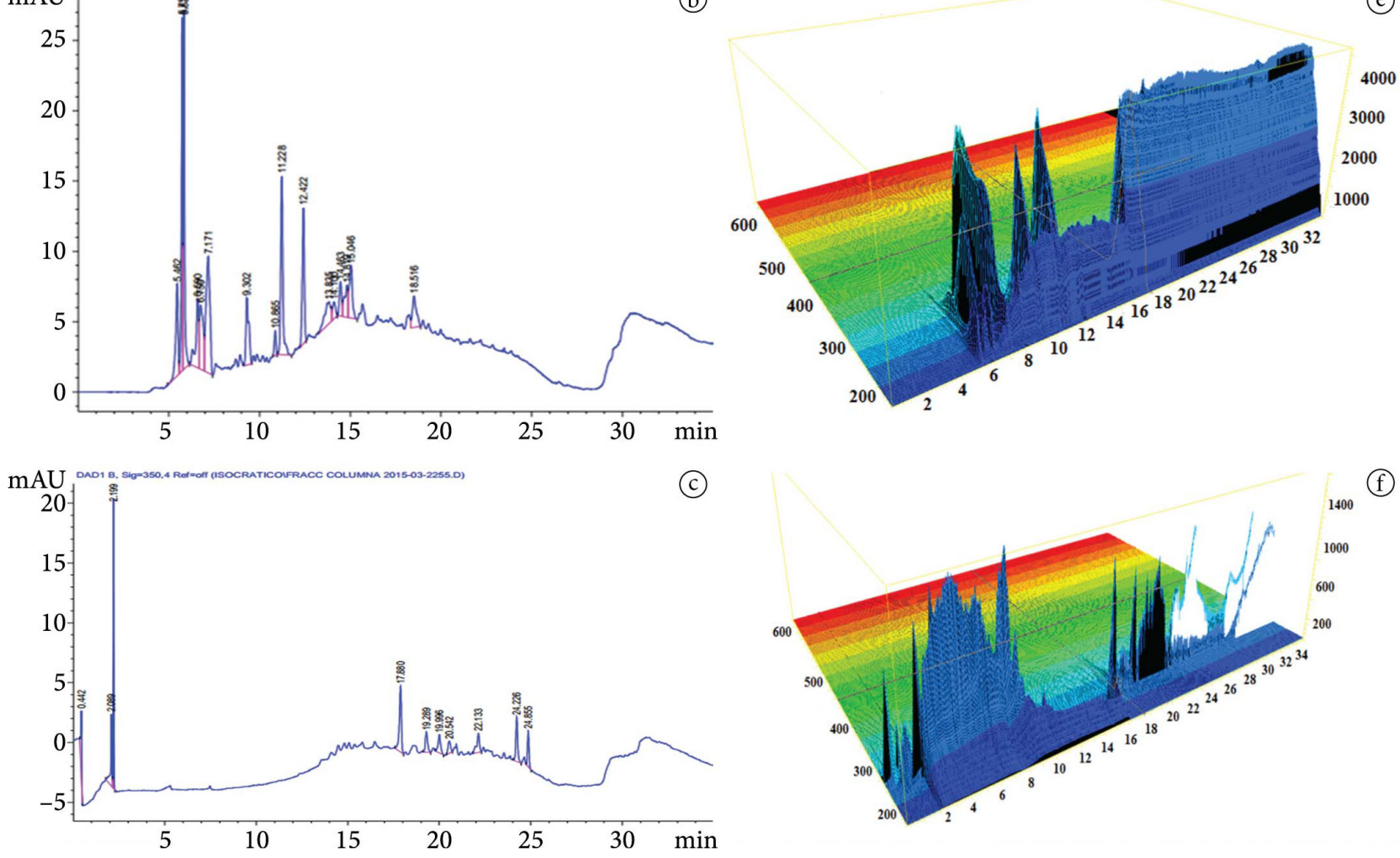

Figure 3. RP-HPLC chromatograms (a-c) and spectrometric scanning (d-f) of methanol-, acetone-, and hexane-soluble fractions, respectively, all obtained from octopus (Paraoctopus limaculatus).

compounds with lower polarity than those found in the MSF. Also, most of the absorption was detected in the near UV spectrum, which is also consistent with the presence of non-polar compounds. Spectrophotometric scanning of the HSF showed absorption signals also in the near UV spectrum (after $18 \mathrm{~min}$ ), also consistent with the presence of non-polar compounds.

\section{6 ${ }^{1} \mathrm{H}$-NMR Analysis}

${ }^{1} \mathrm{H}-\mathrm{NMR}$ analysis of HSF (Figure 4a) shows chemical shifts of the protons between $\delta_{H} 0.7-2.4$ that correspond to hydrogen directly bound to carbon atoms, which is attributed to methine, methyl, and methylene protons.
The spectrum shows the presence of protons bound to carbons attached to an oxygen atom $\delta_{\mathrm{H}} 2.7-5.5$ which may be attributed to functional groups such as alcohols, acetals, esters, ethers, and ketones; however, in this field (between 4.6 and 5.9) signals corresponding to vinyl protons in alkenes may be found, therefore, compounds with conjugated double bond systems may also be present. These conjugated systems have great absorption intensities in the near UV spectrum, which was previously observed in the RP-HPLC scanning analyses. This spectrum shows no characteristic signals of aromatic protons, suggesting that antimutagenic compounds may have different structures, which is consistent with results reported by Cruz-Ramírez et al. 

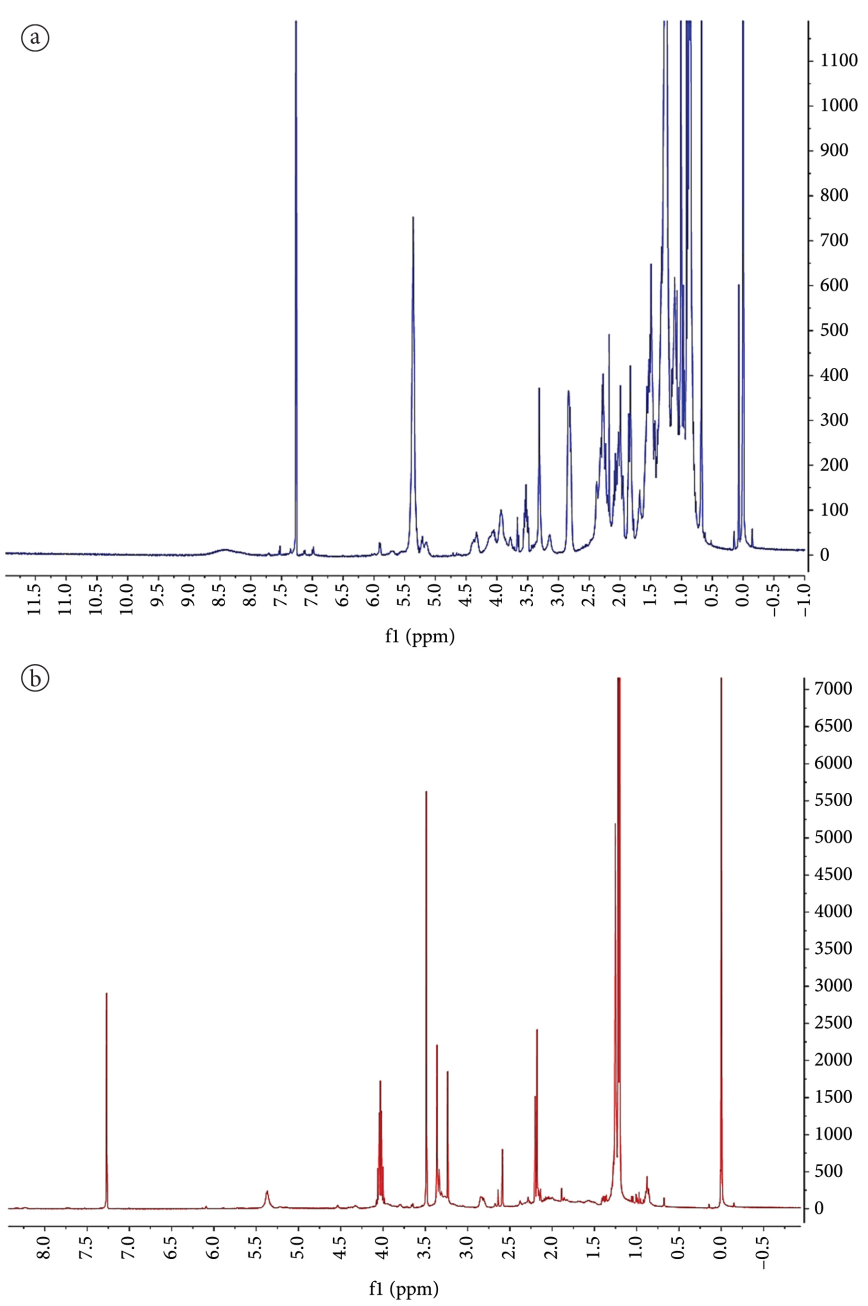

Figure 4. ${ }^{1} \mathrm{H}-\mathrm{NMR}$ spectrum of (a) antimutagenic and antiproliferative hexanic-soluble fraction, and (b) antioxidant methanol-soluble fraction, both obtained from octopus (Paraoctopus limaculatus). TMS was used as a reference.

(2015). ${ }^{1} \mathrm{H}$-NMR spectrum (Figure $4 \mathrm{~b}$ ) of MSF shows irradiation signals of methyl, methylene, and methine $\left(\delta_{\mathrm{H}} 0.6-2.6\right)$, which suggest the presence of protons associated to aliphatic chains. The signals displayed between $\delta_{\mathrm{H}} 3.2-4.0$ correspond to protons adjacent to carbon attached to oxygen atoms. Previously, we discussed that the antioxidant activity of the MSF may due to the presence of phenolic compounds; however, these compounds have a complex aromatic ring system not observed in the ${ }^{1} \mathrm{H}-\mathrm{NMR}$ spectrum $\left(\delta_{\mathrm{H}} 6.0-8.5\right)$, suggesting the presence of different compounds capable of inhibiting ABTS and DPPH radicals.

\section{Conclusions}

Results from this research suggest that HSF from octopus contains antimutagenic and antiproliferative compounds, while potent antioxidant compound are mainly contained in the MSF. Based on RP-HPLC and ${ }^{1} \mathrm{H}-\mathrm{NMR}$ data, both MSF and HSF contain biologically active non-polar compounds, possibly featuring conjugated double-bond systems; however, further research is required for their full characterization.

\section{Acknowledgements}

Authors wish to thank Consejo Nacional de Ciencia y Tecnología (CONACYT) Mexico for financing the project 241133 and for the graduate scholarship granted to SusanaGabriela Cruz-Ramírez.

\section{References}

Althunibat, O. Y., Hashim, R. B., Taher, M., Daud, J. M., Ikeda, J. M., \& Zali, B. I. (2009). In vitro antioxidant and antiproliferative activities of three malaysian sea cucumber species. European Journal of Scientific Research, 37(3), 376-387.

Aqil, F., Zahin, M., \& Ahmad, I. (2008). Antimutagenic activity of methanolic extracts of four ayurvedic medicinal plants. Indian Journal of Experimental Biology, 46(9), 668-672. PMid:18949897.

Athukorala, Y., Lee, K.-W., Song, C., Ahn, C.-B., Shin, T.-S., Cha, Y.-J., Shahidi, F., \& Jeon, Y.-J. (2003). Potential, antioxidant activity of marine red alga Grateloupia Filicina extracts. Journal of Food Lipids, 10(3), 251-265. http://dx.doi.org/10.1111/j.1745-4522.2003.tb00019.x.

Bhattacharya, S. (2011). Natural antimutagens: a review. Research Journal of Medicinal Plant, 5(2), 116-126. http://dx.doi.org/10.3923/ rjmp.2011.116.126.

Cruz-Ramírez, S. G., López-Saiz, C. M., Plascencia-Jatomea, M., MachiLara, L., Rocha-Alonzo, F., Márquez-Ríos, E., \& Burgos-Hernández, A. (2015). Isolation and identification of an antimutagenic phthalate derivative compound from octopus (Paractopus limacualtus). Tropical Journal of Pharmaceutical Research, 14(17), 1257-1267. http://dx.doi. org/10.4314/tjpr.v14i7.19.

Fitahia, E. M., Raheriniaina, C. E., Bazin, M. A., Huvelin, J.-M., Logé, C., Ranaivoson, E., \& Nazih, H. (2015). Anti-proliferative and proapoptotic effect of dichloromethane extract of Octopus vulgaris by-products on human breast cancer Cell Lines. Waste Biomass Valor, 6(2), 237-242. http://dx.doi.org/10.1007/s12649-014-9344-1.

Gulluce, M., Agar, G., Baris, O., Karadayi, M., Orhan, F., \& Sahin, F. (2010). Mutagenic and Antimutagenic effects of hexane extract of some Astragalus species grown in the eastern anatolia region of Turkey. Phytotherapy Research, 24(7), 1014-1018. PMid:19957249.

Jayaraj, S. S., Thiagarajan, R., Arumugam, M., \& Mullainadhan, P. (2008). Isolation, purification -and characterization of [beta]-1,3glucan binding protein from the plasma of marine mussel Perna viridis. Fish \& Shellfish Immunology, 24(6), 715-725. http://dx.doi. org/10.1016/j.fsi.2007.11.012. PMid:18420422.

Jesy, J. H., Thilaga, R. D., \& Mary, J. (2014). Anticancer activity of marine cephalopod (S.Pharaonis) from Gulf of mannar. International Journal of Current Research, 6(11), 10009-10012.

Jie Li, W., Long Cheng, X., Liu, J., Chao Lin, R., Li Wang, G., Shan Du, S., \& Long Liu, Z. (2012). Phenolic compounds and antioxidant activities of Liriope muscari. Molecules (Basel, Switzerland), 17(2), 1797-1808. PMid:22328078.

López-Saiz, C. M., Velázquez, C., Hernández, J., Cinco-Moroyoqui, F. C., Plascencia-Jatomea, M., Robles-Sánchez, M., Machi-Lara, L., \& Burgos-Hernandez, A. (2014). Isolation and structural elucidation of antiproliferative compounds of lipidic fractions from white shrimp muscle (Litopenaeus vannamei). International Journal of Molecular Sciences, 15(12), 23555-23570. http://dx.doi.org/10.3390/ ijms151223555. PMid:25526568.

Maron, D. M., \& Ames, B. N. (1983). Revised methods for the Salmonella mutagenicity test. Mutation Research, 113(3-4), 173-215. PMid:6341825.

Martínez, J. E. (2006). Quimioprevención del cáncer de mamá. Oncologia, 29(1), 16-21. 
Moreno-Félix, C., Wilson-Sánchez, G., Cruz-Ramírez, S. G., VelázquezContreras, C., Plascencia-Jatomea, M., Acosta, A., Machi-Lara, L., Aldana-Madrid, M. L., Ezquerra-Brauer, J. M., Rocha-Alonzo, F., \& Burgos-Hernández, A. (2013). Bioactive lipidic extracts from octopus (Paraoctopus limaculatus): antimutagenicity and antiproliferative studies. Evidence-Based Complementary and Alternative Medicine, 2013, 1-12. http://dx.doi.org/10.1155/2013/273582. PMid:23401709.

Mosmann, T. (1983). Rapid colorimetric assay for cellular growth and survival: application to proliferation and cytotoxicity assays. Journal of Immunological Methods, 65(1-2), 55-63. http://dx.doi. org/10.1016/0022-1759(83)90303-4. PMid:6606682.

Pramanik, K., \& Pandey, A. (2013). Natural compounds: prospective of chemoprevention. Endocrinology \& Metabolic Syndrome, 2(2), 2-3. http://dx.doi.org/10.4172/2161-1017.1000e115.

Rajaganapathi, J., Thyagarajan, S. P., \& Edward, J. K. (2000). Study on cephalopod's ink from anti-retroviral activity. Indian Journal of Experimental Biology, 38(5), 519-520. PMid:11272422.

Samadi, S., Emtyazjoo, M., Khanipour, A. A., Moghadasi, Z., \& Nazarhaghighi, F. (2011). Antimutagenic activity of Chloroformic and Methanolic extracts of muscle, liver and cartilage of Sphyrna lewini with the Ames test. Iranian Journal of Fisheries Sciences, $10(1), 135-142$.

Senthilkumar, P. \& Sudha, S. (2012). Antioxidant and antibacterial properties of methanolic extract of green seaweed Chaetomorpha linum from Gulf of Mannar: Southeast coast of India. Jundishapur Journal of Microbiology, 5(2), 411-415. http://dx.doi.org/10.5812/ jjm. 3400 .

Stankevicins, L., Aiub, C. A., Mazzei, J. L., Lobo-Hajdu, G., \& Felzenszwalb, I. (2008). Cytotoxic, mutagenic and antimutagenic screening of
Arenosclera brasiliensis acetone and ethanol extracts. Genetics and Molecular Research, 7(2), 542-548. http://dx.doi.org/10.4238/vol72gmr460. PMid:18752179.

Sudhakar, S., \& Nazeer, R. (2015). Preparation of potent antioxidant peptide from edible part of shortclub cuttlefish against radical mediated lipid and DNA damage. LWT - Food Science and Technology, 64, 593-601.

Sultana, B., Anwar, F., Mushtaq, M., Aslam, M., \& Ijaz, S. (2014). In vitro antimutagenic, antioxidant activities and total phenolics of clove (Syzygium aromaticum L.) seed extracts. Pakistan Journal of Pharmaceutical Sciences, 27(4), 893-899. PMid:25015457.

Umayaparvathi, S., Arumugam, M., Meenakshi, S., \& Balasubramanian, T. (2013). Studies on Antifungal, Cytotoxic and HPTLC profiles of Mollusks and Echinoderm extracts from Southeast Coast of India. Journal of Medical \& Allied Health Sciences, 2(1), 24-32.

World Health Organization - WHO. (2010). Prevención del cáncer. Retrieved from http://www.who.int/cancer/prevention/es/

Zahin, M., Ahmad, I., \& Aqil, F. (2010a). Antioxidant and antimutagenic activity of Carum copticum fruit extracts. Toxicology In Vitro, 24(4), 1243-1249. http://dx.doi.org/10.1016/j.tiv.2010.02.004. PMid:20149861.

Zahin, M., Aqil, F., \& Ahmad, I. (2010b). Broad spectrum antimutagenic activity of antioxidant active fraction of Punica granatum L. peel extracts. Mutation Research/Genetic Toxicology and Environmental Mutagenesis, 703(2), 99-107. http://dx.doi.org/10.1016/j.mrgentox.2010.08.001. PMid:20708098.

Zahin, M., Aqil, F., Husain, F. M., \& Ahmad, I. (2013). Antioxidant capacity and antimutagenic potential of Murraya koenigii. BioMed Research International, 2013, 1-10. http://dx.doi.org/10.1155/2013/263509. PMid:23853769. 